\title{
DEVELOPMENT OF DNA BIOSENSOR BASED ON SILVER NANOPARTICLES UV-Vis ABSORPTION SPECTRA FOR Escherichia coli DETECTION
}

\author{
Ruth Chrisnasari, Antonius Loren Wijaya and Maria Goretti Marianti Purwanto \\ Department of Biology, Faculty of Biotechnology, Universitas Surabaya, \\ Jalan Raya Kalirungkut, Surabaya 60292, Indonesia. \\ Correspondence author: ruth_c@staff.ubaya.ac.id
}

\begin{abstract}
In this research we reported the synthesis of oligonucleotide-silver nanoparticle (OSN) conjugates and demonstrated their use along with magnetic beads as biosensor for Escherichia colidetection under magnetic field condition. Oligonucleotide DNA probes were conjugated on silver nanoparticles using alkanethiols linker. Two kinds of alkanethiols linker, 11-mercaptoundodecanoic acid (11-MUDA) and 16-mercaptophexadecanoic acid (16-MHDA) were compared to get the best probe conjugation yield and OSN UV-Vis absorption spectra properties. Three different methods of Escherichia coli DNA isolation i.e. Chen and Kuo (1993), Phenol Chloroform Isoamylalcohol (PCI) extraction and boiling lysis were also compared to explore the performance of the biosensor towards the DNA target purity. Detection process through hybridization between the DNA probe and the target was carried out at $55^{\circ} \mathrm{C}$ for 1 hour incubation time. The results showed that 16-MHDA gave higher conjugation yield and higher OSN UV-Vis absorption spectra than 11-MUDA. The biosensor was able to detect the presence of the DNA target which was isolated from the three isolation methods. The best detection signal was achieved by Chen and Kuo isolation method in which it could detect the presence of the DNA target up to $1.3 \mathrm{ng} / \mu \mathrm{L}$.
\end{abstract}

Keywords: DNA biosensor, Silver Nanoparticles, Escherichia coli

\section{INTRODUCTION}

Along with increasing knowledge of nucleic acid structure and function, detection of specific sequences of DNA has gained increased importance. DNA biosensors based on nucleic acid hybridization have been actively developed because of their specificity, speed, portability, and low cost. Recently, there has been considerable interest in using nano materials for DNA biosensors because of their high surface-to-volume ratios, unique optical, electrical, and thermal properties as well as excellent biological compatibilities. Moreover, nanomaterials could be used to increase the amount of immobilized DNA and maintain its biological activity (Sumar and Kumar, 2008; Xu et al., 2009).

One of metal nanomaterials that can be used as biosensor is silver nanoparticles. Silver nanoparticles have been widely applied as DNA biosensor (Thompson et al., 2008), protein biosensor (Chang et al., 2010) and antibacterial agent (Guzman et al., 2009). For biological applications, silver nanoparticles can be conjugated with biospecific recognition molecules such as antibodies, DNA probe molecules or enzymes. Upon binding with biotarget molecules, the binding event can be detected from individual nanoparticles or nanoparticle clusters by monitoring nanoparticle property change or other responses (Huo, 2007). Silver nanoparticles show absorption band in visible light region and give the optimum UV-Vis absorbance spectra at wavelength around $400 \mathrm{~nm}$ (Henglein and Giersig, 1999; Šileikaite et al., 2006). These properties potentially could be used as signal of optical DNA biosensor. Optical detection methods relying on nanoparticle materials functionalized with

ISSN 2413-0877 (c) 2015 The Authors.

Published by KnowledgeE Publishing Services This is an open access article under the CC BY-NC-ND license (http://creativecommons.org/licenses/by-nc-nd/4.0)

Selection and Peer-review under responsibility of the 3rd ICBS-2013

Doi http://dx.doi.org/10.18502/kls.v2i1.180 
oligonucelotides have shown enhanced sensitivity and selectivity compared to conventional assays based on molecular probes (Wang, 2003).

In the past decade, so many papers and review papers have been published to address the development of microbial pathogens biosensors (Ivnitski et al., 1999; Leonard et al., 2003; Arora et al., 2011) One of the most developed microbial pathogen biosensor is biosensor for Escherichia coli. This biosensor has been widely explored because of various infectious effects of Escherichia coli toward human health. Although most of Escherichia coli strains are harmless, but some serotypes produce large quantities of a potent toxin in the digestive tract causes a serious disease such as hemolytic uremic syndrome, which may lead to death in children and adults (Ivnitski et al., 1999; Vogt, 2005; Mao et al., 2006). In this research we have developed DNA biosensor for Escherichia colidetection based on silver nanoparticles absorption spectra. Oligonucleotide DNA probes were conjugated on silver nanoparticles using alkanethiols linker to make the oligonucleotide-silver nanoparticle $(\mathrm{OSN})$ conjugates. Use of alkanethiols linker as capping agents will enable specific interactions with the substrate and facilitate DNA immobilization as (Gupta et al., 2012). The challenge in adopting this technique lies in preventing undesirable interactions between the capping agents that may lead to aggregation of the nanoparticles. Two kinds of alkanethiols linker, 11-mercaptoundodecanoic acid (11-MUDA) and 16-mercaptophexadecanoic acid (16-MHDA) were compared to get the best probe conjugation yield and OSN UV-vis absorption spectra properties.

Detection of the DNA target was carried out by using OSN conjugates along with Magnetic Beads (MB) under magnetic field condition. MB were conjugated with another DNA probes using the most stable non covalent biotin-avidin interaction. MB are a class of nanoparticles that can be manipulated with magnetic fields. The use of MB as zinc sulfide nanoparticles in DNA biosensors has increased (Li et al., 2003; Graham et al., 2005; Kouassi and Irudayaraj, 2006). Zinc sulfide nanoparticles advantage is having free carboxyl groups on their surface that can be easily soluble in water (Zhu et al., 2004). Three different methods of Escherichia coli DNA isolation i.e. Chen and Kuo, Phenol Chloroform Isoamylalcohol $(\mathrm{PCl})$ extraction and boiling lysis were also compared to explore the performance of the biosensor towards the DNA target purity.

\section{MATERIALS AND METHODS}

Reagents and Buffers. Silver nitrate $\mathrm{AgNO}_{3}$, Sodium borohydride $\left(\mathrm{NaBH}_{4}\right)$, Tween 20, 16-Mercaptohexadecanoid acid (16-MHDA), 11-Mercaptoundodecanoic acid (11MUDA), (3-Aminoprpyl)triethoxysilane (APTS), Iron(III)oxide $\left(\mathrm{Fe}_{3} \mathrm{O}_{4}\right)$, n-hydroxysuccinimide (NHS), N-Ethyl-N-(3-dimethylaminopropyl)carbodiimide hydrochloride (EDAC), Imidazole and Avidin in analytical grade purity from Sigma Aldrich were used throughout this study.

Saline Tris EDTA (STE) buffer, Tris EDTA (TE) buffer, Sodium Deodecyl Sulphate (SDS), proteinase $\mathrm{K}$, phenol chloroform isoamylalcohol ( $\mathrm{PCl}$ ), ethanol absolute, $\mathrm{NaCl}$, lysis buffer Chen and Kuo, chloroform and double distilled water $\left(\mathrm{ddH}_{2} \mathrm{O}\right)$ were all in molecular grade.

Probes. Both of DNA probes which immobilized on silver nanoparticles $\left(5^{\prime}-\mathrm{NH}_{2}-\left(\mathrm{CH}_{2}\right)_{6}^{-}\right.$ CAGCGAAAATCCTGTTTCATGGCCC-3') and DNA probes which immobilized on MB (5'CACGGATCCAGACTTTGATACTGGCTCAG-Biotin-3') were obtained from $1^{\text {st }}$ Base, 
Singapore.

Instruments. The spectrofotometric measurements were performed using Thermo Scientific GENESYS 10S UV-Vis spectrophotometer (USA). DNA concentration measurements were conducted on ACTGene ASP-2680 NanoDrop.

Synthesis of Silver Nanoparticles. Silver nanoparticles was synthesized according to Solomon et al. (2007) protocol. Initially, $30 \mathrm{ml}$ of $\mathrm{NaBH}_{4} 0.2 \mathrm{mM}$ placed in $100 \mathrm{ml}$ erlenmeyer flask. The erlenmeyer flask then surrounded by ice placed on beaker glass $500 \mathrm{ml}$ and stirred with a stirrer to homogenize the $\mathrm{NaBH}_{4}$. On separated flask, $10 \mathrm{~mL}$ of $0.1 \mathrm{M}$ $\mathrm{AgNO}_{3}$ were made. After the $\mathrm{NaBH}_{4}$ solution stirred for 20 minutes, $0.2 \mathrm{mM}$ solution of $\mathrm{AgNO}_{3}$ was slowly added while stirring still being done. After 3 minutes, the mixture color will change from colorless to bright yellow.

Synthesis of Alkanethiols Functionalized Silver Nanoparticles (ASN). As much as $10 \mathrm{ml}$ of silver nanoparticles and $10 \mathrm{ml}$ of Tween $20(2 \mathrm{mg} / \mathrm{ml})$ in $10 \mathrm{mM}$ phosphate buffer $\mathrm{pH} 7.0$ were mixed thoroughly in the $50 \mathrm{ml}$ erlenmeyer flask. The mixture was allowed stand for 20 minutes at room temperature and $0.5 \mathrm{mM}$ of 16-MHDA or 11-MUDA in $10 \mathrm{ml}$ of methanol was added. The mixture was stirred overnight. After the stirring process has done, the mixture was centrifuged at $13,000 \mathrm{rpm}$ for $60 \mathrm{~min}$. The supernatant was discarded and the pellets were washed with $\mathrm{dd}_{2} \mathrm{O}$. The washed pellets then resuspend in $10 \mathrm{mlddH}_{2} \mathrm{O}$ and some of it was taken and scanned the absorbance compared with pure silver nanoparticles.

Synthesis of Oligonucleotide-Silver Nanoparticles (OSN). A total of $10 \mu \mathrm{L}$ of 500 $\mathrm{nM}$ amine modified DNA probes was added with $750 \mu \mathrm{LASN}$ and $240 \mu \mathrm{L}$ phosphate buffer $\mathrm{pH}$ 7. The mixture was stirred and incubated for 2-3 hours. After the stirring process has completed, centrifuge the mixture at $13,000 \mathrm{rpm}$ for $30 \mathrm{~min}$. The pellets were washed twice with phosphate buffer $\mathrm{pH} 7$. The washed pellets were resuspended in $750 \mu \mathrm{L}$ phosphate buffer $\mathrm{pH} 7$.

Synthesis of Magnetic Beads (MB). As much as $25 \mathrm{ml} \mathrm{Fe}_{3} \mathrm{O}_{4} 0.0128 \mathrm{~mol} / \mathrm{L}$ was dissolved in $150 \mathrm{ml}$ of ethanol and $1 \mathrm{ml}$ Milli $Q$ water. Then the mixture was sonicated for 30 minutes and added with $35 \mu \mathrm{L}$ APTS and stirred for 7 hours. The mixture was centrifuged and the supernatant discarded. The pellets were washed 5 times using ethanol. Pellets were dried and the dry weight was calculated.

Synthesis of Avidin Coated Magnetic Beads (MB-Avidin). MB was resuspended in milli-Q water $(100 \mu \mathrm{L} 5 \mathrm{mg} / \mathrm{ml})$ and added to a mixture of $890 \mu \mathrm{L}(100 \mathrm{mM}$ imidazole, 100 $\mathrm{mM}$ EDAC, $100 \mathrm{mM} \mathrm{NHS}$ ). The mixture then was added with $10 \mu \mathrm{L}$ Avidin $2 \mathrm{mg} / \mathrm{ml}$ and incubated overnight. After incubation finished, the mixture was centrifuged and the supernatant was discarded. The pellets were then washed with Milli $Q$ water.

Synthesis of Oligonucleotide-Magnetic Beads (OMB). A total of $200 \mu \mathrm{L}$ of MB-Avidin was added with $10 \mu \mathrm{L}$ of biotin modified DNA probe $(500 \mathrm{nM})$ and $90 \mu \mathrm{L}$ of phosphate buffer $\mathrm{pH}$ 7. The mixture was stirred slowly overnight. The next day a mixture centrifuged, the pellets were washed with phosphate buffer $\mathrm{pH} 7$ for twice. The washed pellets then resuspended with $200 \mu \mathrm{L}$ of phosphate buffer $\mathrm{pH} 7$.

E. coli cells Preparation. E. colicells were cultured in Luria Bertani broth overnight at $37^{\circ} \mathrm{C}$ until reached $\mathrm{OD}_{600}$ of 0.6 . Cultured cells were taken and put in a micro tube and then centrifuged at 10,000 rpm for 2 minutes. The supernatant was discarded and the pellet was 
used for further experiments.

Boiling Lysis DNA Isolation Methods. The pellet cells of $E$. coliwas resuspended in $1 \mathrm{ml} \mathrm{ddH}_{2} \mathrm{O}$ and incubated on $90{ }^{\circ} \mathrm{C}$ for $10 \mathrm{~min}$ and centrifugated at $10,000 \mathrm{rpm}$ for $3 \mathrm{~min}-$ utes. The pellet was discarded and the supernatant was added cold absolute ethanol ( $96 \%)$. The solution was allowed to stand at $-4{ }^{\circ} \mathrm{C}$ for 30 minutes and centrifugated at $10,000 \mathrm{rpm}$ for $10 \mathrm{~min}$. The pellet was washed with $70 \%$ of cold ethanol for twice and dried. The dried pellet was taken and dissolved in $50 \mu \mathrm{lddH_{2 }} \mathrm{O}$.

Phenol Chloroform Isoamylalcohol (PCI) DNA Extraction Method. The pellet cells of $E$. coli were resuspended in $500 \mu \mathrm{l}$ of STE buffer. The solution then was centrifuged at 10,000 rpm for 3 minutes. The supaernatant was discarded and the pellet was resuspended and homogenized in $500 \mu \mathrm{l}$ of TE buffer and $100 \mu \mathrm{l}$ of SDS $10 \%$. The solution then was added with $10 \mu \mathrm{l}$ Proteinase- $\mathrm{K}$ and incubated at $37^{\circ} \mathrm{C}$ for an hour. After the incubation process has finished, the solution was added with $500 \mu \mathrm{l}$ of $\mathrm{PCI}$ solution and mix gently for several times. The solution then centrifuged at $10,000 \mathrm{rpm}$ for 10 minutes. The upper aqueous phase was taken and put in new sterilized tube, the cold absolute ethanol (96\%) was added and incubated for 30 minutes then centrifugated. The pellet was washed with $70 \%$ of cold ethanol for twice and dried. The dried pellet was taken and dissolved in $50 \mu \mathrm{lddH} \mathrm{H}_{2} \mathrm{O}$.

Chen and Kuo DNA Isolation Method. The pellet cells of E. coliwas resuspended in $200 \mu \mathrm{l}$ of lysis buffer and $66 \mu \mathrm{l} 5 \mathrm{M} \mathrm{NaCl}$. The solution was centrifuged at 10,000 rpm for 15 minutes. The upper aqueous phase was taken and put in new sterilized tube. The chloroform was added and mixed gently for several times until the color changes into milky white. The solution was centrifuged at 10,000 rpm for 15 minutes. The upper aqueous phase was taken and put in new sterilized tube, the cold absolute ethanol (96\%) was added and incubated for 30 minutes then centrifugated. The pellet was washed with $70 \%$ of cold ethanol for twice and dried. The dried pellet was taken and dissolved in $50 \mu \mathrm{lddH_{2 }} \mathrm{O}$ (Chen and Kuo, 1993).

The DNA Target Detection. The presence of the DNA target was detected by mixing $10 \mu \mathrm{L}$ of DNA target, $50 \mu \mathrm{L}$ of OSN, $20 \mu \mathrm{L}$ of OMB, and $10 \mu \mathrm{L}$ of phosphate buffer $\mathrm{pH}$ 7. The mixture was incubated for an hour at $55^{\circ} \mathrm{C}$. After incubation process has finished, the mixture was placed under magnetic field condition for 5 minutes. The solution was taken and scanned the absorbance at $\lambda 350-480 \mathrm{~nm}$. The presence of the DNA target was shown by decreasing of OSN absorbance spectra. The schematic of the DNA target detection can be seen in Fig. 1 


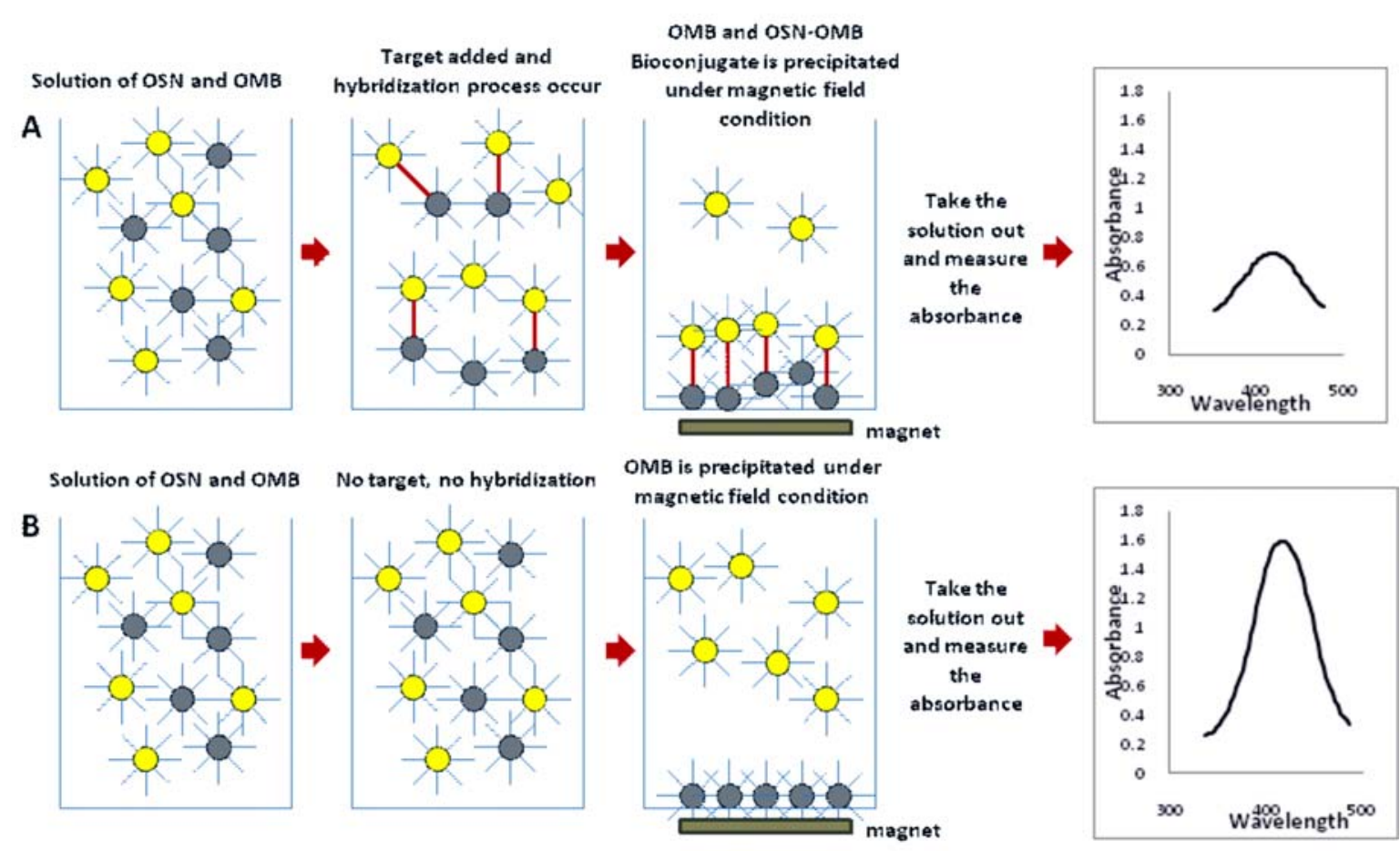

Figure 1. Schematic illustration of the DNA target detection by DNA Biosensor based on silver nanoparticles UV-Vis absorption spectra: (A) In the presence of DNA target, (B) without target

\section{RESULTS AND DISCUSSION}

Synthesis of silver nanoparticles was done in the cold temperature to accelerating the reaction. The nanoparticle formation involving oxidation-reduction reactions that occur as follows: $2 \mathrm{AgNO}_{3}+2 \mathrm{NaBH}_{4}{ }^{\prime} ! 2 \mathrm{Ag}+\mathrm{H}_{2}+\mathrm{B}_{2} \mathrm{H}_{6}+2 \mathrm{NaNO}_{3}$. The reaction goes perfectly when the color of the solution changes from colorless to bright yellow (Jack, 2010). The absorbance measurements showed that the absorption peak was 1.591 at a wavelength of 417 $\mathrm{nm}$. Silver nanoparticles obtained from previous experiments subsequently functionalized with alkanethiol linker 16-MHDA and 11-MUDA. The linker forms a monolayer that serves as attachment of the DNA probes. The good linker will not lead the aggregation of silver nanoparticles and keep the color of the solution bright yellow. The result showed that there was a decreasing absorption peak of both 16-MHDA and 11-MUDA functionalized silver nanoparticles compare to pure silver nanoparticles, but 16-MHDA functionalized silver nanoparticles (ASN-MHDA) showed higher absorbtion peak than 11-MUDA functionalized silver nanoparticles (ASN-MUDA). Interaction between silver nanoparticles and alkanethiol linkers has lead a shift in the maximum wavelength of ASN-MHDA to $408 \mathrm{~nm}$ and $411 \mathrm{~nm}$ for ASN-MUDA, respectively. The addition of DNA probes both on 16-MHDA and 11-MUDA has reduced the absorbance peak. That can be occurs because of attachment of other molecules on the surface of silver nanoparticles may interfere its maximum absorbance (Nair, 2011). The decrease in the maximum absorption peak can also occur because of the loss during centrifugation and washing. The absorption spectra of silver nanoparticles, ASN and OSN can be seen in Figure 2. 


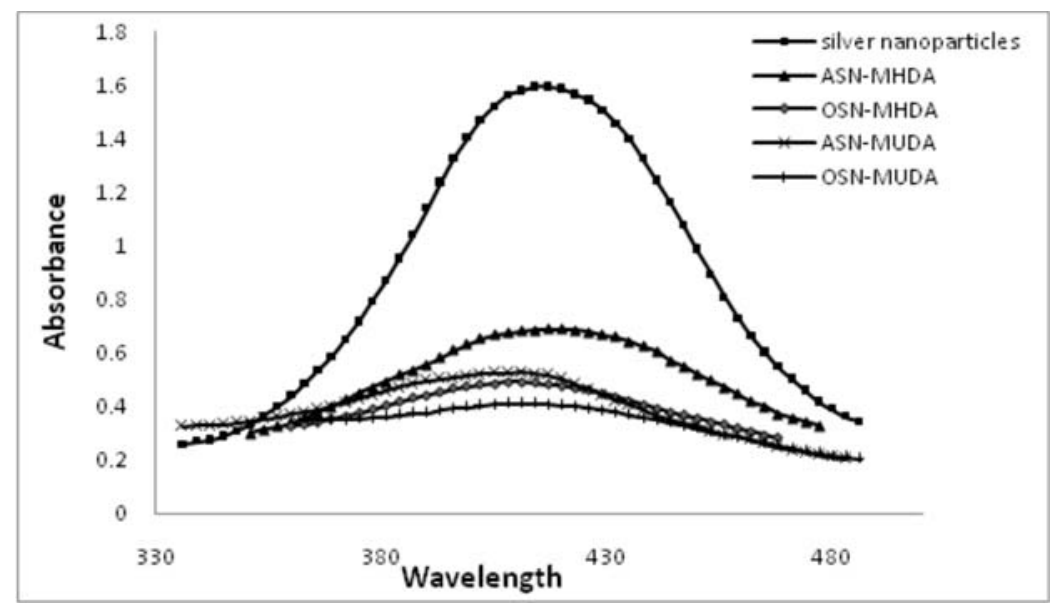

Figure 2. The absorption spectra of silver nanoparticles, alkanethiol functionalized silver nanoparticles (ASN) and oligonucleotide silver nanoparticles (OSN) using different kind of linker.

Three different methods of Escherichia coli DNA isolation i.e. Chen and Kuo, Phenol Chloroform Isoamylalcohol (PCl) extraction and boiling lysis were compared to explore the performance of the biosensor towards the DNA target purity. The characteristic of isolated DNA from the three isolation methods are listed in Table 1. The result showed the highest concentration obtained from Chen and Kuo method, followed by PCl and boiling lysis. Based on the ratio of $\mathrm{A}_{260 / 280}$ or DNA purity, Chen and Kuo and $\mathrm{PCl}$ showed a good result which ratio in the range from 1.8 to 2.0 , while the result of boiling lysis method was not really good, since the ratio was below the range.

The biosensor was able to detect the presence of the DNA target which was isolated from the three isolation methods which indicated by reduction of the OSN absorption spectra. The best detection signal was achieved by Chen and Kuo isolation method which showed the lowest absorption spectra (Fig.3).

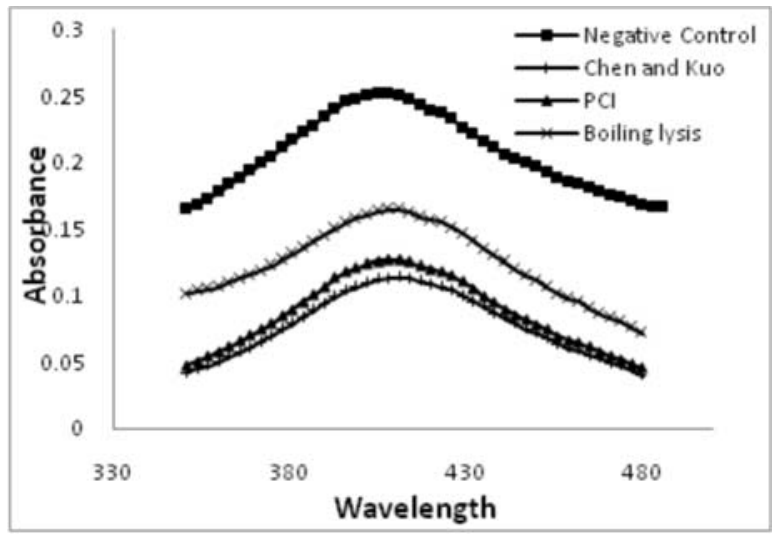

Table 1. The characteristic of isolated DNA from the three isolation methods.

\begin{tabular}{lcc}
\hline Isolation Method & Concentration of DNA $(\mathrm{ng} / \mu \mathrm{l})$ & $\begin{array}{c}\mathrm{A}_{260 / 280} \\
\text { Ratio }\end{array}$ \\
\hline Chen and Kuo & 1331 & 1.868 \\
& 1289 & 1.955 \\
& 1307 & 1.860 \\
\hline $\mathrm{PCl}$ & 1232 & 1.908 \\
& 569 & 2.031 \\
& 498 & 1.872 \\
\hline Boiling Lysis & 428 & 1.738 \\
& 366 & 1.617 \\
& 533 & 1.721 \\
\hline
\end{tabular}

Figure 3. The absorption spectra of oligonucleotide silver nano-particles (OSN) in detecting the presence of DNA target from three different isolation methods. 
The DNA sample which isolated using Chen and Kuo method subsequently was diluted to a dilution series, i.e 10;100,1,000; and 10,000 times to know the limit detection of the DNA biosensor. The result of the experiment showed that the sample concentration was inversely proportional to the decrease of absorbance spectra. From the statistical analysis, the dilution from 10-1,000 times of DNA sample show a significant different with negative control, whereas 10,000 times of dilution has no significant different with negative control (Fig. 4). This result implies that the DNA biosensor could detect the presence of the DNA target up to 1,000 of dilution which concentration $\pm 1.3 \mathrm{ng} / \mu \mathrm{l}$.

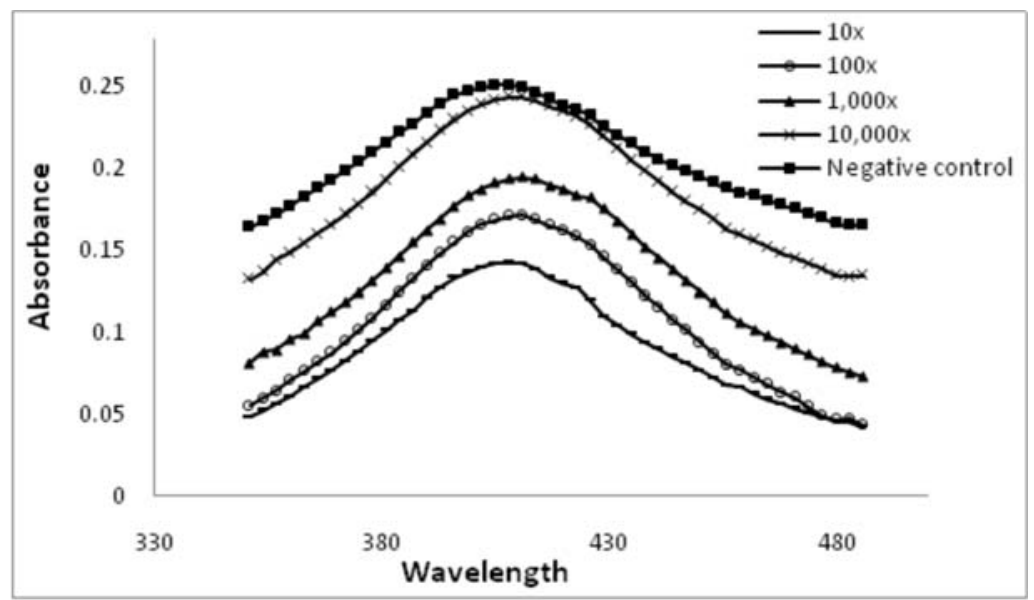

Figure 4. The absorption spectra of oligonucleotide silver nanoparticles (OSN) in the presence of DNA target from different concentration of DNA.

\section{ACKNOWLEDGMENT}

The authors would like to thank to the Research Institution and Public Services of Universitas Surabaya (UBAYA) for the research funding.

\section{REFERENCES}

Arora, P., A. Sindhu, N. Dilbaghi, and A. Chaudhury. 2011. Biosensors as innovative tools for the detection of food borne pathogens. Biosensor Bioeletron. vol. 28. 11-12

Chang, H., L. Tang, Y. Wang, J. Jiang, and J. Li. 2010. Graphene fluorescence resonance energy transfer aptasensor for the thrombin detection. Anal. Chem. vol. 82. 2341-2346 Chen, W.P., and T.T. Kuo. 1993. A simple and rapid method for preparation of gram-negative bacterial genomic DNA. Nucleic Acids Research. vol 21. 2260.

Graham, D.L., H.A. Ferreira, N. Feliciano, P.P. Freitas, L.A. Clarke, and M.D. Amaral. 2005. Magnetic field-assisted DNA hybridisation and simultaneous detection using micronsized spin-valve sensors and magnetic nanoparticles. Sensors and Actuators $B$ : Chemical. vol.107 (2). 936-944. doi:10.1016/j.snb.2004.12.071

Gupta, R.K., M.P. Srinivasan, and R. Dharmarajan. 2012. Synthesis of 16-Mercaptohexadecanoic acid capped gold nanoparticles and their immobilization on a substrate. Mater Lett. vol.67. 315-319

Guzmán, M.G., J. Dille, and S. Godet. 2009. Synthesis of silver nanoparticles by chemical reduction method and their antibacterial activity. Intern J. Chem Biol Engineering. vol. 2 (3), 104-111. 
Henglein, A., and M. Giersig. 1999. Formation of Colloidal Silver Nanoparticles: Capping Action of Citrate. J. Phys. Chem. B 1999, 103, 9533-9539

Huo, Q. 2007. A perspective on bioconjugated nanoparticles and quantum dots. Colloids and Surfaces B: Biointerfaces. vol.59.1-10

Ivnitski, D., I. Abdel-Hamid, P. Atanasov, and E. Wilkins E. 1999. Biosensors for detection of pathogenic bacteria. Biosens Bioelectron. vol.14. 599-624

Jack, B. 2010. Chemical Synthesis of Silver Nanoparticles for Nanoparticles for Light Trapping Applications In Silicon Solar Cells.

Kouassi, G.K., and J. Irudayaraj. 2006. Magnetic and Gold-Coated Magnetic Nanoparticles as a DNA Sensor. Anal. Chem. vol.78 (10). 3234-3241. DOI: 10.1021/ac051621j

Leonard, P., S. Hearty, J. Brennan, L. Dunnea, J. Quinn, T. Chakraborty, and R. O'Kennedy. 2003. Advances in biosensors for detection of pathogens in food and water. Enzyme Microb Tech. vol.32. 3-13

Li, G., V. Joshi, R.L. White, S.X. Wang, J.T. Kemp, C. Webb, R.W. Davis, and S. Sun. 2003. Detection of single micron-sized magnetic bead and magnetic nanoparticles using spin valve sensors for biological applications. J. Appl. Phys. vol.93. 7557.doi:10.1063/1. 1540176

Mao, X., L. Yang, X. Su, and Y. Li. 2006. A nanoparticle ampliûcation based quartz crystal microbalance DNA sensor for detection of Escherichia coli O157:H7. Biosensors and Bioelectron. vol 21. 1178-1185

Nair, N., N. Wentzel, and A. Jayaraman.2011. Effects of polydispersity on Potential of Mean Force between Functionalized Nanoparticles in a Homopolymer Mat rix: Self-Consistent PRISM Theory-Monte Carlo Simulation Study'J. Chem Phys. vol. 134, 194906

Šileikaite, A., I. Prosycevas, J. Puiso, A. Juraitis, and Guobiene. 2006. Analysis of Silver Nanoparticles Produced by Chemical Reduction of Silver Salt Solution. Mater Sci. vol. 12 (4). 287-291.

Solomon, S.D., M. Bahadory, A.V. Jeyarajasingam, S.A. Rutkowsky, C. Boritz, and L. Mulfinger. 2007. Synthesis and Study of Silver Nanoparticles. J Chem Edu, 322-325.

Sumar, A. Kumar. 2008. Recent Advances in DNA Biosensor. Sensors Transducers J. vol. 92 (5). 122-133

Thompson, D.G., A. Enright, K. Faulds, W.E. Smith, and D. Graham. 2008. Ultrasensitive DNA Detection Using Oligonucleotide-Silver Nanoparticle Conjugates. Anal. Chem. vol. 80. $2805-2810$

Vogt, R.L., and L. Dippold. 2005. Escherichia coli O157:H7 outbreak associated with consumption of ground beef, June-July 2002. Public Health Rep. vol.120 (2). 174-8.

Wang, J. 2003. Nanoparticle-based electrochemical DNA detection. Analytica Chimica Acta. vol. 500. 247-257

Xu, K., J. Huang, Z. Ye, Y. Ying, and Y. Li. 2009, Recent Development of Nano-Materials Used in DNA Biosensors. Sensors, vol. 9. 5534-5557; doi:10.3390/s90705534

Zhu, N., A. Zhang, P. He, and Y. Fang. 2004. DNA Hybridization at Magnetic Nanoparticle with Electrochemical Stripping Detection. Electroanalysis. vol.16 (23). 1925-1930. DOI:10.1002/elan.200303028. 